\title{
THE SYSTEM AND STRUCTURE OF THE SOCIAL ECONOMY IN THE SLOVAK REPUBLIC
}

\author{
Peter Plavčan $^{1}$, Petronela Šebestová ${ }^{2}$
}

\begin{abstract}
The 20-ties of the $21^{\text {st }}$ century are dented by the COVID-19 period. The fall of the world economy, the frustrations of the inhabitants because of their health, and unclear state policies throughout continents require functional measures. The application of the principles of social economy enables creation of the working system of sustainable entrepreneurial activities with the help of state means, transforming small and middle-sized enterprises into a social economy. The knowledge on the system and organization structure of the social economy in the Slovak Republic enables dissemination and potential application in the international context in the current pandemic period characterized by COVID-19. The system of social economy is being defined by Slovak legal regulations and selected statistic indicators about the social economy subjects in the Slovak Republic. A part of it is also a structural classification of the organizational structure of the state administration of the social economy, classification of the kinds of social enterprises, as well as classification of the wider area of the social economy from the multiple points of view in the Slovak Republic. The research results can be used as an argument for implementing of social economy in national economies.
\end{abstract}

UDC Classification: 364-7, DOI: https://doi.org/10.12955/pss.v2.237

Keywords: social economy, social enterprise, enterprise with a social impact, wider area of the social economy

\section{Introduction}

The 20-ties of the $21^{\text {st }}$ century are dented by the COVID-19 period. The fall of the world economy, the frustration of inhabitants born from their health concerns, and unclear state policies throughout the continents require functional measures. Various economic measures throughout various states to support the improvement of the unfavorable state in the economic sector in the area of small and middle-sized entrepreneurship. The implementation of the principles of social economy in national economies is a tool to improve the economic situation of the marginalized groups of inhabitants without using social networks and by means of various forms of donations for the wages of employees, refunds for the rent of the premises used for business and so on. Social economy enables the creation of a functional system of sustainable small and middle-sized entrepreneurship with the help of state means. The donation is rendered to transform small and middle-sized businesses into a social economy, and performed economic activity is funded. Financial support of the state based on the social economy principles is more perspective as to solve the unemployment in small and middle-sized businesses by means of a social network. Social networks currently do not support creativity, development but rather the same views, as a result of which we move along our beaten paths of thought. This fact can greatly affect the formation of an individual's identity, and we do not yet know to what extent it will affect our lives (Mareková, 2020).

This paper aims to present knowledge on the system and organizational structure of the social economy in the Slovak Republic, disseminate knowledge on Slovak social economy, and enable potential implementation of this information in the international context in the current pandemic COVID-19 period.

\section{Goals and methodology}

In the paper, we rely on the thesis on the usefulness of information on social economy and on possibilities that can be provided to disadvantaged and vulnerable physical persons, but also to the small and middle-sized entrepreneurs, whose entrepreneurial activity requires saving or resuscitation of their business in the international and national context. The research problem in this paper is the proposition of the structural description of the social economic system in the Slovak Republic and mainly the preparation of the classification of the organization structure of the social economy and social enterprises from multiple points of view in the Slovak Republic.

The paper is based mainly on theoretical analysis, and its results have potential value for further research in the social sciences. The main research methods in this paper are special methods used in the context of the social sciences. Historical-logical analysis of social data, the process of analogy, transfer of basic principles of social sciences to the Slovak and world economy are used.

\footnotetext{
${ }^{1}$ Danubius University, Faculty of Social Studies, Sládkovičovo, Slovakia, peter.plavcan@ vsdanubius.sk

${ }^{2}$ Danubius University, Faculty of Social Studies, Sládkovičovo, Slovakia, petronela.sebestova@gmail.com
} 


\section{The significance of social economy for the public interest}

In the last two centuries, the Czech economists came with socio-economic approaches that did not lay the profit in the first place. Based on this tradition that reaches into the $19^{\text {th }}$ century, many non-profit organizations associating with people have been founded during the $1^{\text {st }}$ Czechoslovak Republic from 1918 to 1938 (part of which was also Slovakia) (CIRIEC, 2012).

Big problem and obstacle in the social economic development in the Slovak Republic was incomplete legislation and statistic of the third sector, voluntary activities, and social entrepreneurship up to 2017. This has caused its insufficient evaluation and presence. Except for that, the system of financial help to support activities of the social economy was missing. The information on social economy and its tools to support research good practice examples were not on sufficient level. Through the adoption of Act no. 112/2018 on Social Economy and Social Enterprises in the Slovak Republic, the conditions for the usage of the semi labor market have been created, which means that the employee in the social enterprises will be able to gain work habits within a year or two. Then it will be easier for them to find lasting employment. The Act's main intention is to create a favorable environment for social business, bring order into this business as for terms and regulations, and tackle obstacles that stand in the way of social economic development. The inevitable condition is the definition of rules so that it doesn't come to the misuse of social enterprises and state grants. (Šebestová, Mačkinová 2019).

The currently most publically acceptable definition of social economy is published in Social Economy Charter and goes as follows (CEP-CMAF, 2002): the importance of people and the social objective over capital, voluntary and open membership, democratic control by the membership (does not apply to foundations, as these have no members), the combination of the interest of members, users or general society interest, the defense and application of the principles of solidarity and responsibility, autonomous management and independence from public authorities and reinvestment of the essential surplus to carry out sustainable development objectives, services of interest to members or general interest.

\section{The social economy as part of the state}

In the first third of the $20^{\text {th }}$ century, the interventions of social economy in Europe were relatively preferred. In the Western European states, in the period from 1945 to 1975, the economic model of the state was composed mainly of the traditional private business sector and state public sector. This model was a basis for the social state that focused on the identified failures of the market and implemented economic measures that worked for the market failures: the distribution of the income and costs and the anti-cyclic measures. These resulted from the Keynesian economic model, in which the big social and economic partners were employer federations, trade unions, and the government represented state.

In the states of Central and Eastern Europe with their centrally planned economies in the period from 1945 to 1989 , the state was the only economic agent and did not render many possibilities for other economic subjects to implement the rules of social economy. The organizations having a legal form of cooperatives were relatively popular in these states. These were mainly cooperatives of agricultural nature or ones that were active in the fond housing administration. Some of the traditional rules of these cooperatives, e.g., voluntary and open membership and democratic organization, have not applied. In the last two centuries, the Czech economists came with socio-economic approaches that did not lay the profit in the first place. Based on this tradition that reaches into the $19^{\text {th }}$ century, many non-profit organizations associating with people have been founded during the $1^{\text {st }}$ Czechoslovak Republic (1918 to 1938) (CIRIEC, 2012).

A socially important question of general interest concerning imbalance in the regional development, cyclic unemployment, or relations between retailers and consumers could have been solved with the help of big-scale of companies and organizations in the form of cooperatives, mutual companies, and associations created in a mixed economy.

According to the Act on Social Economy and Social Enterprises in the Slovak Republic, a social economy is "a collection of productive, distribution and consumption activities performed by means of economic activity or non-economic activity independent on state authorities whose aim is to achieve positive social influence" (Ministry of Labour, Social Affairs and Family of the Slovak Republic, 2018) 
Positive social influence, as defined by the Act on Social Economy, is the support of employment by employing disadvantaged persons or vulnerable persons and providing socially beneficiary rental accommodation.

According to the aforementioned legal regulations, the social economy did not relate to entrepreneurship. The terms "social" and "economy" in the previous period only presented a connection between social services for inhabitants and economical insurance mainly from public sources. A relatively small part of financial means was directed to social services by means of $2 \%$ of the income tax of physical and legal persons for the non-profit organizations. These financial means were partially mediated by means of contribution but have not emerged directly in social services.

The social economy is a collection designation of personal and material sources of the entire subjects performing economic or non-economic activity on the market in public, community interest, but also to the benefit of disadvantaged and vulnerable persons in order to achieve direct positive social influence on society, region, village, community or physical persons.

During the last decades, three types of strategic orientation of building social enterprises have been created. The first type focuses on decreasing cost for the production and distribution, so the enterprise makes an effort to offer the products to the customers for a price lower than the competition. The second type is known for its perfect performance as for the value for the customer e.g., services, technical level, the social aspect of the business, etc. As for the third type of strategy, the social enterprise of this type only focuses on one market segment and strives to gain a leading position on the market within this one segment. The third type is also the most typical strategic solution for the whole Central Europe (Šebestová, 2019)

There is a stereotype that the costs for social services, so-called the meritorious goods, are considered social costs and are therefore supposed to be equal to consumption that the social distribution invests into the cultural field from sources created in material production. When investing means into meritorious goods, the economic result - profit-is created, while this profit could be measured in financial or non-financial effects. The result of the activities in these fields is a service, the usefulness of which is being seen directly or in a mediated way for society. A healthier, more cultural, and educated population brings more effects to the national economy than just work productivity. A further reason for the underestimation of these goods is the fact that the activity performed in these fields - education and upbringing, health care, social security of the citizens, but also saving rescue of cultural sights, etc. do not have any specific market value according to their usefulness in the society and costs mainly influence their value. They are generally perceived as free, although useful, but without value and therefore without social seriousness (Plavčan, 2020, 1). Secondly, political and professional bodies' decisions to increase education expenditure have positively affected the quality of education at schools in general, regardless of how the economy is doing (Plavčan, 2020, 2).

\section{Subjects of social economy}

The social economy is oriented on the realization of production, distribution, and consumption activities, even if profit maximization is here not the goal. The physical persons and legal person participating in the development of social economy focus on specific social benefit of their activity, providing a socially beneficiary service. That is why the physical and legal persons include specifically established organizations that focus on the gain of the profit and organizations that are primarily established to help out in social services in the fields, where the state does not cover.

The subject of social economy is similar to that in other states of the world, is such an organization in the form of civic organization, foundation, non-investment fund, non-profit organization, targeted church institutions, Business Company, cooperation or physical person - an entrepreneur who is also an employer.

The legal regulation in the Slovak Republic establishes requirements for legal persons as follows (Ministry of Labour, Social Affairs and Family of Slovak Republic, 2018): " are not ruled by state bodies by the majority, the state body does not do majority of their financing, does not appoint and elect statutory bodies, nor more than a half of their members and does not appoint and elect more than half of the member of the managing or advisory board, perform economic or non-economic activity as a part of social economy activities, If they perform entrepreneurial or other profitable activity according to the 
specific regulation, they do not perform those exclusively in order to achieve profit, or they use this profit in compliance with this act."

The social economy is generally understood as a collection of activities of subjects that are being performed by means of economic and non-economic activity independently from the state bodies, but using their financial influence on their activities. However, in the Slovak Republic, the law does not enable the strong influence of state bodies by means of the minority management of the subject of social economy, therefore by means of minority representation of the members of the management body or advisory body.

\section{Social enterprise}

According to the Act on Social Economy and Social Enterprises, the Social Economy subject is - a civic organization, foundation, non-investment fund, non-profit organization, specialized church institution, business company, cooperative or physical person - an entrepreneur who is also an employer and who: performs the economic activity continuously, independently, in his own name and on his own responsibility, whose primary goal is to achieve measurable positive social influence, while these products and services are produced, delivered, provided or distributed by this entity or if the nature of the production or the provision contributes to the creation of these products and service, which, if it achieves profit from its activity resulting into more than $50 \%$ of the profit after taxation in order to achieve the measurable positive social influence, will distribute a share of the profit in compliance with processes and rules that do not break the main goal and who engages interested persons in the management of its economic activity (Ministry of Labour, Social Affairs and Family of Slovak Republic, 2018).

The enterprise with an active social impact in the economy might have one of the following legal forms: civic organization, foundation, non-profit organization, specialized church institution, Business Company, cooperation or physical person - an entrepreneur who performs his activity and has to achieve positive social influence in his activity, while complying at least two of these conditions: "the products or services being produced, delivered, provided or distributed that contribute to the positive social influence or if the nature of their production or provision does, they will use more than $50 \%$ of the profit of the activity that intends to achieve the positive social influence after taxation, to achieve this main goal and they engage interested persons in the management of their economic activity, the goal of which is the achievement of the positive social influence (Ministry of Labour, Social Affairs and Family of Slovak Republic, 2018)

The social enterprise and the enterprise with social impact for this Act are enterprises in a wider area of social economy that include investment, compensation, and demand support.

\section{Registered social enterprise}

The statute (registration as a social enterprise) that the social enterprise will get by fulfilling conditions of registrations stipulated by law. After having fulfilled conditions, the registered social enterprise will start to use a description: registered social enterprise or the relevant abbreviation with its name. The registered social enterprise may also be established by merging, division or fusion with other registered social enterprises.

The kinds of registered social enterprise can be divided into various groups from various points of view: according to the structure of people living in certain spaces and the specialization of the activity.

These are the kind of social enterprises with the meaning of the Act on Social Economy and Social Enterprises:

According to the structure of the society of the people living in certain space (society, community): public service enterprises and community service enterprises.

According to the specialization of the activity: integration enterprises, social enterprises in housing, and general registered social enterprises.

As for the structure of the society of people living in certain spaces (society, community), the registered social enterprises might be public service-oriented ones and community service-oriented ones. The public service enterprises contribute with their activities to the public benefit or general use that is connected with the general benefit, while community service registered social enterprises concern 
community - the society of people living in the same social, cultural or religious space, sociability as in sharing the common space.

As for the specialization of the activities, the registered social enterprise can be an integration one, social enterprise in housing, or a general registered social enterprise.

Table 1: Selected indicators about registered social enterprise in SR - year 2021

\begin{tabular}{|c|c|c|c|c|c|c|c|c|c|}
\hline & \multicolumn{9}{|c|}{ Self-governing regions } \\
\hline & BA & TT & NT & ZA & TN & $\mathrm{BB}$ & $\mathrm{PO}$ & KE & Total \\
\hline The amount of registered social enterprises & 11 & 20 & 17 & 44 & 46 & 40 & 39 & 66 & 283 \\
\hline in \% & 3.9 & 7.0 & 6.0 & 15.5 & 16.3 & 14.1 & 13.8 & 23.3 & 100 \\
\hline \multicolumn{10}{|l|}{ Kinds of social enterprises } \\
\hline Integration enterprise & 11 & 10 & 15 & 43 & 44 & 33 & 37 & 59 & 252 \\
\hline $\begin{array}{l}\text { Integration enterprise and general reg. soc. } \\
\text { ent. }\end{array}$ & - & 9 & 1 & 1 & 2 & 6 & 1 & 7 & 27 \\
\hline $\begin{array}{l}\text { Integration enterprise and soc. enterprise in } \\
\text { housing }\end{array}$ & - & - & - & - & - & - & 1 & - & 1 \\
\hline $\begin{array}{l}\text { Integration enterprise and general reg. soc. } \\
\text { ent. and soc. enterprise in housing }\end{array}$ & - & - & 1 & - & - & - & - & - & 1 \\
\hline General reg. soc. ent. & - & 1 & - & - & - & 1 & - & - & 2 \\
\hline \multicolumn{10}{|l|}{ Legal forms of social enterprises } \\
\hline Limited liability & 10 & 17 & 16 & 40 & 43 & 33 & 37 & 62 & 258 \\
\hline Civic association & 1 & 1 & - & 1 & 3 & 1 & 1 & 3 & 11 \\
\hline Non-profit org. & - & 2 & - & 2 & - & 2 & - & - & 6 \\
\hline Physical pers. - ent. & - & - & - & 1 & - & - & 1 & - & 2 \\
\hline Cooperative & - & - & 1 & - & - & 4 & - & 1 & 6 \\
\hline
\end{tabular}

Note 1: BA - Bratislava self-governing region, TT - Trnava self-governing region, NT - Nitra self-governing region, ZA - Žilina self-governing region, TN - Trenčín self-governing region, BB - Banská Bystrica selfgoverning region, $\mathrm{PO}$ - Prešov self-governing region, $\mathrm{KE}$ - Košice self-governing region

Note 2: reg. soc. ent. - Registered social enterprise, Limited liability. - Limited liability company, non-profit org. - non-profit organization, Physical person ent. - entrepreneur

Source: Ministry of Labour, Social Affairs and Family of Slovak Republic (2021).

From table 1, the following is to be interpreted: Almost one quarter (23.3\%) of all the registered social enterprises is located in Košice self-governing region. The second group is composed of four regions that have a share of $14-16 \%$ on all the registered social enterprises, and those are in ascendant order: Trenčín self-governing region, Žilina self-governing region, Banská Bystrica self-governing region, Prešov self-governing region. In the group with the lowest share of all the registered social enterprises are the following in descending order: Trnava self-governing region (7.0\%), Nitra self-governing region $(6.0 \%)$, and Bratislava self-governing region $(3.9 \%)$.

The analysis of the kinds of social enterprises has shown that of all the registered social enterprises up to $89 \%$ are integration enterprises. The analysis has also shown that as for the legal form of registered social enterprises, the Limited Liability Companies dominate with $91 \%$ of all the registered social enterprises. Despite a relatively considerable amount of cooperative, whose tradition persists in the Slovak Republic since the $2^{\text {nd }}$ half of $20^{\text {th }}$ century, it has been proven that these have surprisingly not been interested in registering as social enterprise with the corresponding benefits.

\section{The wider area of social economy}

Various subjects enter the economy to perform economic activities as physical persons or legal persons, including civic organizations, foundations, non-investment funds, non-profit organizations, specialized church institutions, business companies, cooperatives, or physical persons - entrepreneurs.

The wider area of social economy, as for the socially beneficiary service in social economy divides as follows: provision of health care; provision of social support and humanitarian care; creation, development, protection, restoration and presentation of spiritual and cultural values; protection of human rights and fundamental freedoms; education, upbringing, and development of physical culture; research, development, scientific-technical services, and information services; creation and protection of the environment and health protection of inhabitants; services supporting regional development and 
employment; safeguarding of accommodation, administration, maintenance and reconstruction of residential housing.

The wider area of social economy as for the socially beneficiary service intervenes with its scope of activity in almost all the fields of society, in democracy, culture, social affairs, education, science and technology, creation and protection of the environment, and further fields of human development.

The wider area of a social economy according to the extent of the specialization of the economic activity of economic subjects into socially beneficiary activity with positive social impact divide into social enterprises and enterprises with social impact.

Economic subjects, civic organizations, foundations, non-investment funds, non-profit organizations, specialized church organizations, business companies, cooperatives, or physical persons - entrepreneurs are all considered enterprises of social economy if they are performing socially beneficiary activity with a positive social impact. All the aforementioned subjects, except for the non-investment funds, can be with the meaning of the law described as enterprises with social impact, if the main goal of at least one economic activity is to achieve the positive social influence.

From the regional point of view, the wider area of social economy is created by the structure and amount of subjects of social economy and quantification of their social impact according to the individual regions of the Slovak Republic: self-governing regions and districts (villages).

From the regional point of view, the wider area of social economy is composed of all the social economy subjects that are registered as social enterprises or enterprises with social impact from the aspect of the regional structure in the area of Slovak Republic, as divided into self-governing regions or districts. The quantification of the structure, the amount of social economy subjects, and quantification of their social impact on regions and districts or villages creates presumptions for the evaluations of the functionality of the Act on Social Economy and Social Enterprises as well as the possible intervention of social measures in the economically underdeveloped regions.

The wider area of social economy seen from the perspective of the size of the achieved positive influence is created by the economical subjects, who: do not achieve positive social influence, achieve positive social influence, and outperform positive social influence.

The achievement of the positive social influence in the integration enterprise in compliance with the Act on Social Economy and Social Enterprises is fulfilled if the integration enterprise employs at least 30\% of disadvantaged and vulnerable persons in its organization in order to achieve the positive social influence in the social enterprise in housing, if this enterprise is constructing or reconstructing in compliance with building permission, at most however up to three years since the issuance of the building permit.

\section{Support in a wider area of social economy}

The support in a wider area of social economy with the meaning of the Act on Social Economy and Social Enterprise is an investment, compensation help, and support of the demand for the activities performed in compliance with special regulations in the field of state aid that are being performed in the area of Slovak Republic.

The investment support and compensation support can be provided to the social enterprise that is not a registered social enterprise, to the enterprise with a social impact in the form of a financial tool that provides finances in the form of a combination of the reimbursable support and non-reimbursable support. The Act on Social Economy and Social Enterprises does not regulate the mutual ratio of the combination of reimbursable support and non-reimbursable support.

The enterprise in the wider area of social economy has a duty to return the provide support or its aliquoted share after the taxation depreciation have been done on the long term intangible property and long term tangible property or if it breaks the provisions of the Act on Social Economy and Social Enterprises or these of general acts.

\section{The organizational structure of state administration in the social economy}

The central body of state administration in the Slovak Republic for the field of labor and unemployment, family and social support, as well as social insurance and retirement system is the Ministry of Labour, Social Affairs and Family of Slovak Republic (Ministry of Labour, Social Affairs and Family of Slovak republic, 2001). 
The Ministry of Labour, Social Affairs and Family of Slovak Republic is the central body of state administration for the social economy that divides as follows: the highest umbrella organization of the sector of social politics and umbrella organization of the sector of social politics (social enterprise registered social enterprise, integration enterprise, a social enterprise in housing, generally registered social enterprise and enterprise with social impact).

A specific task of the Ministry is the provision for education in the field of social economy by means of training and courses concerning mainly interpretation of relevant legal regulations in the field of social economy and of practical courses regarding social enterprises. In the meaning of the Act on Social Economy and Social Enterprises, the national projects in the field of social economy are being processed and realized directly by the organization of the resort of Labour, Social Affairs and Family, being the Head office of the Labour, Social Affairs and Family of the Slovak Republic that manages, controls and coordinates and methodically directs the performance of state administration in the field of social affairs and unemployment services. The performance of services is being covered by the Offices of Labour, Social Affairs and Family.

\section{Conclusion}

The social economy offers possibilities for the organization and implementation of social support, mainly in the economy of small and middle-sized businesses. The social support in this form is positively perceived by a great part of inhabitants, especially those of middle and lower levels, which is visible e.g., in the developed unpaid voluntary activities. For groups of people sharing this opinion, the social economy and its principles are understood as a fairer and more human process in economies of national states. The social economy includes fair trade, ecologic groceries or ethical financing, a big part of it is also paid or unpaid voluntary activities. A significant part of the social economy is educational and upbringing activities, as neglected upbringing and education of children are hard to correct in older age (Plavčan, 2019).

The principles of social economy and its implementation in the life of society change people's thinking about economy and contribute to bigger collective social solidarity that is so needed to current COVID19 times and will also be necessary in the following period. The social economy enterprise and enterprises with social impact are currently in national economies that have been emphasized because of their significant integrational function. These enterprises have an important impact on marginalized groups of inhabitants that currently are more segregated than ever before.

In order to solve the research problem, this paper described the system of social economy on the basis of Slovak legal regulation as well as on the basis of selected statistic indicators about social economy subjects in the Slovak Republic. In parallel, structural classification of the organizational structure of the state administration in the social economy has been prepared and the classification of the kinds of social enterprises. The paper also presents a classification of the wider area of the social economy from various aspects in the Slovak Republic.

\section{References}

CEP-CMAF (2002). The Social Economy. amice-eu.org/userfiles/file/2007_08_20_EN_SE_charter.pdf

CIRIEC (2012). The social economy in the European Union. Summary of the Report drawn up for the European Economic and Social Committee by the International Centre of Research and Information on the Public, Social and Cooperative Economy (CIRIEC). QE-31-12-784-EN-C

Mareková, H. (2020). Crisis of identity in the context of macro-social changes. Prague: International Conference on Innovations and Science education. March 18-20, 2020. E-ISSN 2695-0715 (Online), P-ISSN 2695-0723 (Print), DOI: https://doi.org/10.12955/pss.v1.63

Ministry of Labour, Social Affairs and Family of the Slovak Republic (2021). Register sociálnych podnikov [Register of social enterprises]. Bratislava: Ministerstvo práce, sociálnych vecí a rodiny SR. employment.gov.sk/sk/pracazamestnanost/socialna-ekonomika/

Ministry of Labour, Social Affairs and Family of the Slovak Republic (2018). Zákon č. 112/2018 Z. z. o sociálnej ekonomike a sociálnych podnikoch [Act no. 112/2018 Coll. on the social economy and social enterprises]. Bratislava: Ministerstvo práce, sociálnych vecí a rodiny SR. https://www.slov-lex.sk/pravne-predpisy/SK/ZZ/2018/112/

Ministry of Labour, Social Affairs and Family of the Slovak Republic (2001). Zákon č. 575/2001 Z. z. o organizácii činnosti vlády a organizácii ústrednej štátnej správy [Act no. 575/2001 Coll. on the organization of government activities and the organization of the central state administration]. Bratislava: Ministerstvo vnútra SR. https://www.zakonypreludi.sk/zz/2001575 
Plavčan, P. (2020). Sociálna a vedomostná ekonomika [Social and knowledge economy]. Brno: MSD. ISBN 978-80-7392$352-5$

Plavčan, P. (2020). The comparison of PIRLS, TIMSS and PISA educational results in member states of the European Union. Prague: International Conference on Innovations and Science education. March 18-20, 2020. E-ISSN 2695-0715 (Online), PISSN 2695-0723 (Print), DOI: https://doi.org/10.12955/pss.v1.70

Plavčan, P. (2019). The comparison of PISA educational results with gross domestic product in member states of European Union. Prague: International Conference on Innovations and Science education. March 20-22, 2019. In Journal Contact. Print ISSN 1805-997X, Online ISSN 1805-9961.

Šebestová, P. (2019). Projektový manažment sociálnych podnikov [Project management of social enterprises]. Brno: MSD 2019. 168 s. ISBN 978-80-7369-315-0

Šebestová, P., Mačkinová M. (2019). Development of social economy and social entrepreneurship in Slovakia. Prague: International Conference on Innovations and Science education. March 20-22, 2019. In Journal Contact. Print ISSN 1805997X, Online ISSN 1805-9961 